\title{
HUBUNGAN ANTARA PSYCHOLOGICAL WELL-BEING DENGAN ENGAGEMENT LEARNING PADA MAHASISWA
}

\author{
Sepdi Putera Anugerahnu ${ }^{1}$ Rudangta Arianti ${ }^{2}$ \\ Email: rudangta.sembiring@uksw.edu ${ }^{2}$ \\ Fakultas Psikologi Universitas Kristen Satya Wacana Salatiga, ${ }^{1,2}$
}

\begin{abstract}
This research was aimed to find out the correlation between psychological well-being and learning engagement among college students. The population used in this research were the active or not in leave students of UKSW's Faculty of Psychology, starting from the class of 2016 to the class of 2019. Purposive quota sampling were used as sampling methods on 91 students participants. The measurement scale used on this research were referred from Carol Ryff's scale of psychological well-being (1989) and engagement learning index constructed by Schreiner \& Louis (2006). The results of this research indicates a positive and significant relation between PWB and engagement learning $(r=0498 ; p<0,05)$, this indicates that the higher the psychological well-being of college students, the higher the learning engagement of the college students, conversely the other way around. With additional results showing PWB has $24,8 \%$ contribution on engagement learning.
\end{abstract}

Keywords: Engagement Learning, Psychological Well-Being

\begin{abstract}
Abstrak
Psychological well-being dan engagement learning merupakan beberapa hal yang perlu diperhatikan guna meningkatka sistem pendidikan yang lebih baik. Penelitian ini bertujuan untuk meneliti hubungan antara psychological well-being dengan engagement learning pada mahasiswa. Populasi pada penelitian ini adalah mahasiswa Fakultas Psikologi UKSW yang merupakan mahasiswa aktif dan tidak dalam status cuti kuliah, mulai dari angkatan 2016 sampai angkatan 2019. Teknik sampling yang digunakan dalam penelitian ini adalah purposive quota sampling dengan partisipan sebanyak 91 mahasiswa. Alat ukur yang digunakan dalam penelitian ini mengacu pada Skala psychological well-being disusun menurut Carol Ryff (1989) yang bernama psychological well-being scale (PWBS) dan untuk engagement learning diukur menggunakan skala Engaged Learning Index (ELI) yang disusun berdasarkan penelitian Schreiner \& Louis (2006). Hasil dari penelitian ini menunjukan bahwa terdapat hubungan positif yang signifikan antara PWB dengan engagement learning $(\mathrm{r}=0498 ; \mathrm{p}<0,05)$, hal ini menujukan bahwa semakin tinggi psychological well-being pada mahasiswa maka semakin tinggi pula engagement learning pada mahasiswa tersebut, begitu pula sebaliknya. Dengan hasil tambahan bahwa PWB memiliki kontribusi sebesar 24,8\% terhadap engagement learning.
\end{abstract}

Kata Kunci: Engagement Learning, Psychological Well-Being

\section{PENDAHULUAN}

Universitas Kristen Satya Wacana (UKSW) merupakan salah satu perguruan tinggi yang ada di Indonesia, dimana UKSW juga memiliki peran yang sama dengan perguruan tinggi lainnya yang ada di Indonesia yaitu, menjalankan maupun menciptakan sistem pendidikan yang baik. Salah satu peran UKSW dalam pendidikan adalah mencetak profil lulusan mahasiswa yang berkualitas atau sesuai dengan tujuan UKSW yaitu ingin mencetak profil lulusan yang memiliki karakter minoritas yang berdaya cipta menurut Notohamidjojo dalam buku (Kreativitas yang bertanggung jawab Dr. O. Notohamidjojo, S.H). Dalam mencetak profil lulusan yang berkualitas tentu perlu adanya sistem pendidikan yang baik pula yang diterapkan. Banyak hal yang perlu diperhatikan oleh UKSW maupun perguruan tinggi lainnya sehingga proses pendidikan pada mahasiswanya dapat terus berjalan dengan baik.

Beberapa hal yang perlu diperhatikan agar proses pendidikan yang mahasiswa jalani dapat berjalan dengan baik, salah satunya 
yaitu kondisi psikologis pada mahasiswa (Cehyan \& Cehyan, 2011). Kondisi psikologis mahasiswa perlu diperhatikan mengingat proses mahasiswa selama kuliah tidaklah selalu berjalan dengan baik, dikarenakan mahasiwa selama kuliah mereka juga harus menghadapi perubahan geografis, kemudian mahasiswa juga harus menghadapi kerasnya akademisi, dan lingkungan interpersonal yang sama sekali baru (Michael, Huelsman, Gerard, Gilligan, Gustafson, 2006). Jika mahasiswa bisa mengatasi hal tersebut maka mahasiswa dapat menjalani proses pendidikan dengan baik (Cehyan \& Cehyan, 2011), yang mana hal ini juga akan mengarah kepada terbentuknya kondisi psikologis yang baik atau kondisi psikologis yang positif. Kondisi psikologis yang positif tentunya membawa kepada terwujudnya kesejahteraan psikologis (psychological well-being) dalam diri mahasiswa.

\section{Psychological well-being (PWB)} merupakan istilah yang digunakan untuk menggambarkan kesehatan psikologis individu berdasarkan pemenuhan kriteria fungsi psikologi positif (Ryff, 1989). Lebih lanjut Ryff (1989) menjelaskan ada enam dimensi yang menggambarkan PWB seseorang yaitu, penerimaan diri (selfacceptance). Kedua, hubungan yang positif dengan orang lain (positive relations with others). Kemampuan individu untuk mampu memberi cinta dan perhatian kepada orang lain merupakan salah satu indikasi kondisi mental yang sehat. Ketiga, kemandirian (autonomy). Seseorang dengan fully functioning digambarkan sebagai individu yang memiliki internal locus of evaluation, Keempat, penguasaan lingkungan (enviromental mastery). Kelima, tujuan hidup (purpose in life). Dimensi ini menjelaskan kemampuan individu untuk menemukan makna dan arah kehidupan berdasarkan pengalaman pribadi, dan untuk menyusun tujuan hidupnya (Ryff \& Singer, 2003). Keenam, pengembangan pribadi (personal growth). Kebutuhan akan aktualisasi diri dan menyadari potensi diri merupakan perspektif utama dari dimensi personal growth. Dari keenam dimensi yang sudah dijelaskan sebelumnya, dapat menjelaskan seberapa baik PWB yang dimiliki oleh individu.

Beberapa penelitian terkait PWB juga menjelaskan bahwa, individu yang memiliki PWB yang tinggi, maka individu tersebut akan memiliki perasaan perkembangan yang berkesinambungan, melihat diri tumbuh dan berkembang, terbuka terhadap pengalaman baru, memiliki kepekaan untuk menyadari potensinya, mencari peningkatan pada diri dan prilaku dari waktu ke waktu, memiliki perubahan dalam cara merefleksikan pengetahuan diri dan efektifitas yang lebih baik (Papalia, dkk 2008). Dan jika melihat pada kondisi mahasiswa, PWB juga ditemukan memiliki beberapa manfaat atau hal yang positif terhadap proses pendidikan mahasiswa.

Salah satu manfaat PWB pada mahasiswa yaitu, dalam hal meningkatkan prestasi akademik mahasiswa. Mahasiswa yang memiliki PWB yang baik, maka prestasi 
akademik yang dimilikinya juga akan baik, hal ini di dukung oleh penelitian yang mengatakan bahwa PWB memiliki korelasi positif dengan prestasi akademik (Prajitno, 2015). Jika melihat penjelasan sebelumnya terkait gambaran apabila individu yang memiliki PWB tinggi, maka bisa disimpulkan PWB yang tinggi membawa pengaruh yang baik untuk individu atau pada mahasiswa terkhususkan pada pendidikan. Oleh karena itu mahasiswa perlu memiliki PWB yang baik sehingga dapat membantu proses pendidikan mahasiwa selama berkuliah. Selain memperhatikan kondisi psikologis atau PWB pada mahasiswa, hal lainya yang perlu diperhatikan guna pendidikan dapat berjalan dengan baik adalah dengan memperhatikan keterlibatan mahasiswa dalam proses belajar selama kuliah, atau biasa disebut sebagai engagement learning.

\section{Engagement learning ialah suatu} energi positif yang diberikan dalam pembelajaran sendiri, yang dibuktikan dengan meaningful processing, perhatian pada apa yang terjadi pada saat ini dan keterlibatan dalam kegiatan pembelajaran (Schreiner \& Louis, 2006). Menurut Schreiner \& Louis (2006) engagement learning terdiri dari beberapa aspek, aspek yang pertama yaitu meaningful processing, diartikan sebagai proses kognitif dari informasi baru dan upaya untuk menghubungkan materi baru dengan pengetahuan yang sudah ada sebelumnya atau menentukan relevansinya. Aspek kedua yaitu participation, aspek ini menjelaskan tentang pembelajaran mahasiswa melalui keterlibatan aktif dan berkontribusi dalam diskusi kelas. Aspek yang terakhir yaitu focused attention, aspek ini menjelaskan bagaimana mahasiswa memberikan perhatian kognitif selama berada dikelas. Mengingat pentingnya enggament learning dalam pendidikan tentu terdapat beberapa manfaat apabila mahasiswa memiliki enggament learning.

Beberapa manfaat yang bisa didapatkan apabila mahasiswa memiliki engagement learning yaitu, memperoleh achievemant dan dapat terhindar dari drop out (Fredericks, Blumenfeld \& Paris 2004). Selain itu Hyde (2009) juga mengatakan bahwa, siswa yang terlibat dalam kegiatan belajar, terutama di kelas, jauh lebih mungkin memiliki prestasi yang baik dibandingkan dengan yang tidak terlibat dalam kegiatan tersebut.

Beberapa faktor yang dapat menyebabkan meningkatnya engagement learning menurut Fredericks, Blumenfeld \& Paris (2004), faktor yang pertama adalah school level-factor. Faktor yang kedua yaitu classroom context yang terdiri dari; teacher support, peers, classroom structure, autonomy support, task characteristics. Faktor yang terakhir yaitu individual needs yang terdiri dari; need for relatedness yang didefinisikan sebagai kebutuhan untuk merasa aman dalam menjalin relasi sosial dengan lingkungan sekitar dan kebutuhan untuk mendapatkan pengalaman bahwa dirinya adalah orang yang berguna, orang yang mampu memberikan cinta dan penghargaan; need for autonomy di definisikan sebagai keinginan untuk 
melakukan sesuatu karena alasan pribadi, daripada melakukan sesuatu karena dipengaruhi oleh orang lain; need for competence didefinisikan sebagai kebutuhan untuk mengalami diri sebagai orang yang mampu memproduksi hasil yang diinginkan dan menghindari hasil yang negatif.

Berdasarkan penjelasan sebelumnya terkait beberapa faktor yang dapat menyebabkan meningkatnya engagement learning menurut Fredericks, Blumenfeld \& Paris (2004) disebutkan salah satunya adalah faktor individual need. Faktor individual need terdiri dari beberapa komponen, salah satu komponen tersebut adalah need for autonomy. Need for autonomy di definisikan sebagai keinginan untuk melakukan sesuatu karena alasan pribadi, daripada melakukan sesuatu karena dipengaruhi oleh orang lain (Ryan \& Connell, 1989). Connel \& Wellborn (1991) juga mengatakan, individu yang terpenuhi need for autonomy mereka akan lebih terlibat dalam proses belajarnya.

Selain peran need for autonomy dalam meningkatkan engagement seseorang dalam proses belajarnya, Fredericks, Blumenfeld \& Paris (2004) juga menjelaskan bahwa faktor lainya yang dapat meningkatkan engagement seseorang dalam proses belajarnya adalah peran peers. Dimana dengan memiliki relasi yang baik dengan orang lain atau teman kuliah, dapat diperoleh beberapa hal positif dari relasi tersebut, salah satunya yaitu seseorang bisa mendapatkan dukungan dari temanya, baik itu di dalam lingkungan perkuliahan ataupun diluar lingkungan perkuliahan sehingga seseorang tersebut lebih merasa nyaman dan berminat dalam mengikuti kuliah, hal ini di dukung oleh pernyataan menurut Hurlock 1992 dalam Sarifah \& Edwina (2015) bahwa minat dipengaruhi oleh dukungan sosial di antaranya teman sekelas dan sikap teman sebayanya. Sehingga hal tersebut dapat menimbulkan kebutuhan mahasiswa untuk menjadi lebih berminat dalam mengikuti kuliah. Selain itu Dennis, Phinney \& Chuateco (2005) juga mengatakan, motivasi pribadi, motivasi karir, dukungan teman sebaya juga berpengaruh pada suksesnya mahasiswa dalam mengikuti kuliah.

Apabila ditelusuri lebih dalam lagi, faktor-faktor seperti need for autonomy dan peers yang telah dijelaskan sebelumnya sebagai faktor yang dapat meningkatkan engagement learning seseorang, bisa dikatakan bahwa faktor-faktor tersebut merupakan bentuk dari fungsi kondisi psikologis yang positif (positive psychological functioning) yang diajukan oleh PWB. Maka berdasarkan latar belakang sudah dijelaskan sebelumnya oleh peneliti dimana terdapat beberapa hal seperti keterkaitan antara faktorfaktor yang dapat mempengaruhi engagemet learning dengan beberapa dimensi yang ada pada PWB, oleh sebab itu peneliti ingin meneliti lebih dalam lagi apakah ada hubungan antara PWB dengan engagement learning pada mahasiswa dan sejauh ini penelitian terkait PWB dalam hal pendidikan masih belum banyak diteliti di Indonesia, sejauh ini penelitian terkait PWB dalam 
konteks pendidikan yang sudah ada yaitu, penelitian terkait hubungan PWB dengan prestasi akademik, hubungan PWB dengan optimesme, namun penelitian yang meneliti keterkaitan antara PWB denga engagment learning masih belum banyak di teliti, sehingga hal ini memperkuat peneliti untuk meneliti lebih dalam terkait hal ini.

Tentu dalam penelitian ini juga terdapat manfaatnya, manfaat dalam penelitian ini adalah dapat memberi referensi bagi pihak perguruan tinggi maupun universitas dalam menemukan metode-metode untuk meningkatan sistem pendidikan sehingga menghasilkan kualitas pendidikan lebih baik lagi, misalnya perguruan tinggi maupun universitas bisa menemukan metodemetode yang dapat meningkatkan PWB pada mahasiswanya dan membuat mahasiswanya merasa memiliki keterlibatan pada saat mereka menjalani proses perkuliahan, yang dimana baik PWB dan engagement learning memiliki manfaat positif dalam dunia pendidikan. Berdasarkan latar belakang dan landasan teori yang dikemukakan, maka hipotesis penelitian dari penelitian ini adalah "ada hubungan positif yang signifikan antara psychological well-being dengan engagement learning pada mahasiswa"

\section{METODE PENELITIAN}

Partisipan dalam penelitian ini ialah para mahasiswa fakultas psikologi UKSW. Dimana dari populasi tersebut akan dipilih partisipan dengan karakteristik tertentu yang disesuikan dengan topik dari peneliti sendiri.
Karakteristik tersebut yaitu, mahasiswa fakultas psikologi UKSW mulai dari angkatan 2016 sampai angkatan 2019 dan mahasiswa aktif atau tidak dalam status cuti kuliah. Data penelitian yang digunakan dalam penelitian ini merupakan data primer yang diperoleh dengan menggunakan daftar pertanyaan (kuisioner) dalam versi online atau google form, karena responden dapat berpartisipasi dengan mengakses melalui jaringan internet dan memudahkan proses pengumpulan dan pengolahan data. Jumlah responden yang menjadi subjek penelitian sebanyak 91 mahasiswa dari fakultas psikologi UKSW, yang aktif atau tidak dalam status cuti kuliah mulai dari angkatan 2016 sampai angkatan 2019.

Alat ukur yang digunakan dalam penelitian ini menggunakan, Skala psychological well-being disusun menurut Carol \& Ryff (1989) yang bernama psychological well-being scale (PWBS) Skala engagement learning diukur dengan skala engaged learning index (ELI) disusun berdasarkan penelitian Schreiner \& Louis (2006). Skala ini akan dikembangkan sendiri oleh peneliti dan di ukur dengan menggunakan skala likert yang terdiri dari empat kategori jawaban yaitu "sangat sesuai" hingga "sangat tidak sesuai".

Analisis aitem. Diskriminasi analisis data aitem-aitem valid pada skala PWBS dan skala ELI menggunakan ketentuan Azwar (2012) yaitu aitem dikatakan valid apabila korelasi setiap faktor bernilai positif dengan nilai $\geq 0,2$. Peneliti menggunakan 0.2 agar 
probabilitas item yang gugur lebih sedikit. Dalam pengujiannya pada skala PWBS peneliti menguji validitas pada aitem pernyataannya secara perdimensi, dikarenakan PWB terdiri dari beberapa dimensi yang dimana tiap-tiap dimensi tersebut memiliki bobot atau nilai yang sama antar dimensinya sehingga harus dilakukan analisis aitem secara perdimensi sedangkan untuk skala ELI peneliti melakukan analisis aitem pada skala tersebut secara keseluruhan, dikarenakan pada skala ELI terdiri dari berbagai macam aspek bukan dimensi sehingga harus dilakukan analisis aitem secara keseluruhan. Dengan hasil final alat ukur yaitu, dimensi selfaccepatance 5 item yang valid; dimensi positive relation item 8 yang valid; dimensi autonomy 8 item yang valid; dimensi enviromental mastery 6 item yang valid; dimensi personal growth 6 item yang valid; dimensi purpose in life 7 yang item valid dan untuk skala engagement learning terdapat 22 item yang valid.

Uji Reliabilitas. Sama halnya pada saat analisis aitem, peneliti dalam menguji reliabilitas pada skala PWBS, semua aitem pernyataannya dilakusan secara perdimensi dan untuk skala ELI peneliti menguji reliabilitas semua aitem pernyataan pada skala tersebut secara keseluruhan. Berdasarkan hasil uji reliabilitas di atas dapat diketahui bahwa, pada skala PWBS untuk dimensi selfaccepatance memiliki koefisien alpha cronbach's sebesar $(0,672)$; positive relation $(0,760)$; autonomy $(0,672)$; enviromental mastery $(0,658)$; personal growth $(0,580)$; purpose in life $(0,748)$. Sehingga berdasarkan kriteria menurut Azwar (2012) bisa disimpulkan alat ukur PWBS untuk dimensi autonomy, environmental mastery, self acceptance dan personal growth dinyatakan cukup reliabel, sedangkan untuk dimensi positive relation, purpose in life bisa dikatakan reliabel dan untuk skala ELI, untuk keseluruhan itemnya memiliki koefisien alpha cronbach's sebesar 0,848 sehingga berdasarkan kriteria menurut Azwar (2012) skala ELI bisa dikatakan reliabel.

Untuk mengukur tinggi rendahnya skor PWB digunakan rumus kategorisasi jenjang dari Azwar (2012), yang disusun seperti tabel 1 dibawah.

Tabel 1. PWB

\begin{tabular}{l|l|l|l}
\hline Interval & Kategori & Frekuensi & Persentase \\
\hline$X<118$ & Rendah & 12 & $13,20 \%$ \\
\hline $118 \leq X<140$ & Sedang & 64 & $70,30 \%$ \\
\hline $140 \leq X$ & Tinggi & 15 & $16,50 \%$ \\
\hline & & & \\
\hline Total & & 91 & $100 \%$ \\
\hline Min= 104 & Max= 154 & Mean= 129,14 & SD $=11.07$ \\
\hline
\end{tabular}

Untuk mengukur tinggi rendahnya skor engagement learning digunakan rumus jenjang dari Azwar (2012), yang disusun seperti tabel 2 dibawah.

Tabel 2. Engagement learning

\begin{tabular}{l|l|l|l}
\hline Interval & Kategori & Frekuensi & $\begin{array}{l}\text { Persenta } \\
\text { se }\end{array}$ \\
\hline $\mathrm{X}<55$ & Rendah & 8 & $8,8 \%$ \\
\hline $55 \leq \mathrm{X}<67$ & Sedang & 64 & $70,3 \%$ \\
\hline $67 \leq \mathrm{X}$ & Tinggi & 19 & $20,9 \%$ \\
\hline & & & \\
\hline Total & & 91 & $100 \%$ \\
\hline Min=45 & Max=78 & Mean=61,92 & $\begin{array}{l}\text { SD= } \\
6.44\end{array}$ \\
\hline
\end{tabular}


Sebelum melakukan uji korelasi sesuai dengan tujuan dalam penelitian ini, terlebih dahulu peneliti melakukan uji asumsi yang terdiri dari uji normalitas dan uji linearitas.

Uji normalitas yaitu untuk mengetahui apakah data dalam suatu penelitian berdistribusi normal atau tidak. Residual berdistribusi normal jika nilai signifikansi (nilai probabbilitas $=p$ ) lebih dari 0,05 (Santoso, 2000). Berdasarkan hasil penelitian, variabel PWB setelah nilai masingmasing T-skor untuk tiap-tiap dimensinya dijumlahkan kemudian dan diuji normalitas datanya maka diperoleh nilai signifikansi Kolmogorov- Smirnov sebesar 0,2.

Dan untuk masing-masing dimensi yang ada pada PWB diperoleh nilai signifikansi Kolmogorov- Smirnov yaitu: selfaccepatance $(0,000)$; positive relation $(0,002)$; Autonomy (0,117); enviromental mastery $(0,000)$; purpose in life $(0,000)$; personal growth $(0,000)$. Sehingga bisa dikatakan variabel psychological well-being yang sudah dijadikan satu dengan cara menjumlahkan nilai T-skor untuk tiap-tiap dimensinya, bisa dikatakan berdistribusi normal karena memiliki signifikansi lebih dari 0,05 dan untuk masing-masing dimensi pada PWB, hanya dimensi autonomy saja yang berdistribusi normal karena memiliki signifikansi lebih dari 0,05 , sedangkan dimensi enviromental mastery, personal growth, positive relation, purpose in life, self acceptance tidak berdistribusi normal karena nilai signifikansinya tidak lebih dari 0,05 .
Sehingga untuk pengujian korelasinya, untuk dimensi autonomy akan menggunakan uji korelasi pearson sedangkan untuk dimensi PWB yang lainnya akan menggunakan uji korelasi spearman rho.

Untuk variabel engagement learning memiliki nilai signifikansi KolgomorovSmirnov sebesar 0,2 sehingga bisa dikatakan berdistribusi normal karena nilai signifikansi variabel engagement learning lebih dari 0,05. Dengan demikian untuk variabel engagement learning bisa dikatakan berdistribusi normal. Kemudaian dalam uji korelasinya akan digunakan uji korelasi pearson.

Hasil uji linearitas dilakukan untuk mengetahui linearitas hubungan antara variabel PWB dengan engagement learning dan untuk mengetahui signifikansi penyimpangan dari linearitas hubungan tersebut. Dalam hal ini hubungan PWB dengan engagement learning adalah linear, karena nilai $\mathrm{F}$ hitung lebih kecil dari $\mathrm{F}$ tabel (F hitung $=1,003, \mathrm{~F}$ tabel $=1,97)$ dan memiliki nilai signifikansi untuk linearitas sebesar $0,525(\mathrm{P}>0,05)$.

Kemudian untuk uji linearitas antar dimensi-dimensi PWB dengan engagement learning, hanya dimensi personal growth saja yang hubungannya tidak linear dengan engagement learning sedangkan dimensi lain seperti self-accepatance, positive relation, autonomy, enviromental mastery, purpose in life memiliki hubungan yang linear.

Sebelum melakukan uji korelasi, untuk variabel psychological well-being peneliti terlebih dahulu menghitunng masing- 
masing nilai standar (Z-skor) pada tiap- tiap dimensi yang ada di PWB, dikarenakan PWB terdiri dari beberapa dimensi yang dimana tiap-tiap dimensi tersebut memiliki bobot atau nilai yang sama antar dimensinya. Kemudian setelah diketahui nilai Z-skor untuk tiap-tiap dimensinya, langkah selanjutnya yang dilakukan adalah mengubah nilai Z-skor tersebut menjadi skor yang terstandar (T-skor) agar skor standarnya(Z-skor) tidak menghasilkan nilai yang negatif. Kemudian setelah diketahui T-skor pada masing-masing dimensi yang ada di PWB, peneliti selanjutnya mengkombinasikan atau menjumlahkan T-skor pada tiap-tiap dimensi tersebut, yang dimana nilai T-skor yang sudah dikombinasikan dari tiap- tiap dimensi ini lah yang akan di uji korelasinya dengan variabel satunya, yaitu variabel engagement learning.

Berdasarkan hasil perhitungan uji korelasi, diperoleh koefisien korelasi (r) antara PWB dengan engagement learning sebesar 0,498 dengan $\operatorname{sig}=0,000(\mathrm{P}<0,05)$ yang artinya PWB dengan engagement learning memiliki hubungan positif signifikan dan kedua variabel tersebut memiliki tingkat korelasi yang sedang. Dapat dilihat pada tabel 3.

Tabel 3 Uji Korelasi PWB dengan Engagement Learning

\begin{tabular}{l|l|l|l}
\hline \multicolumn{2}{l|}{ Correlations } & PWB & EL \\
\hline & & 1 & $.498^{* *}$ \\
\hline PWB & Pearson Correlation & & .000 \\
\hline & Sig. (1-tailed) & 91 & 91 \\
\hline & N & $.498^{* *}$ & 1 \\
\hline & Pearson Correlation & .000 & \\
\hline & Sig. (1-tailed) & 91 & 91 \\
\hline & N & \multicolumn{2}{l}{}
\end{tabular}

Hasil uji korelasi antara dimensi yang ada pada PWB dengan engagement learning antara lain: korelasi antara self-acceptance dengan engagement learning menunjukan korelasi (r) sebesar 0,461 dan signifikansi sebesar $0,000(\mathrm{p}<0,05)$; korelasi antara positive relations with others dengan engagement learning menunjukan korelasi (r) sebesar 0,393 dan signifikansi sebesar 0,000 ( $\mathrm{p}<0,05)$; korelasi antara autonomy dengan engagement learning menunjukan korelasi ( $\mathrm{r}$ ) sebesar 0,359 dan signifikansi sebesar 0,000 ( $\mathrm{p}<0,05)$; korelasi antara environmental mastery dengan engagement learning menunjukan korelasi (r) sebesar 0,478 dan signifikansi sebesar 0,000 $(\mathrm{p}<0,05)$; korelasi antara purpose in life dengan engagement learning menunjukan korelasi (r) sebesar 0,346 dan signifikansi sebesar 0,001 ( $\mathrm{p}<$ 0,05); korelasi antara personal growth dengan engagement learning menunjukan korelasi ( $\mathrm{r}$ ) sebesar 0,457 dan signifikansi sebesar 0,000 ( $\mathrm{p}<0,05)$. Berdasarkan hasil korelasi tiap-tiap dimensi PWB terhadap engagement learning, maka bisa disimpulkan bahwa semua dimensi yang ada pada PWB memiliki korelasi dengan engagement learning dan pada penelitian ini juga menunjukan bahwa dimensi environmental mastery memiliki korelasi yang paling tinggi dengan engagement learning dibandingkan dengan dimensi yang lainnya.

Selanjutnya, berdasarkan uji koefisien determinasi, juga ditemukan bahwa PWB memberikan kontribusi sebesar 24,8 \% terhadap engagement learning pada mahasiswa yang dapat dilihat pada Tabel 4. 
Tabel $4 \mathbf{R}^{2}$

Model Summary

\begin{tabular}{l|l|l|l|l}
\hline Model & $\mathrm{R}$ & $\begin{array}{l}\mathrm{R} \\
\text { Square }\end{array}$ & $\begin{array}{l}\text { Adjusted R } \\
\text { Square }\end{array}$ & $\begin{array}{l}\text { Std. Error of } \\
\text { the Estimate }\end{array}$ \\
\hline 1 & $.498^{\mathrm{a}}$ & .248 & .239 & 5616 \\
\hline
\end{tabular}

a. Predictors: (Constant), PWB

\section{HASIL DAN PEMBAHASAN}

Berdasarkan hasil pengujian hipotesis, menujukan bahwa terdapat hubungan positif yang signifikan antara psychological wellbeing dengan engagement learning pada mahasiswa. Hal ini dibuktikan dengan koefisien korelasi sebesar 0,498 dengan sig= $0,000(\mathrm{P}<0,05)$ yang artinya semakin tinggi psychological well-being pada mahasiswa maka semakin tinggi pula engagement learning pada mahasiswa tersebut. Terdapat beberapa hal yang dapat mendukung hal ini, salah satunya yaitu, jika mengacu kepada definisi PWB oleh Ryff dalam Oetari (2017) dijelaskan bahwa PWB merupakan suatu kajian ilmu psikologi positif mengenai bagaimana penilaian manusia mengenai kelebihan dan kekurangan dalam dirinya serta pengembangan potensi optimal yang dimiliki.

Sehingga berdasarkan pengertian tersebut bisa dikatakan bahwa PWB identik dengan psikologi positif dan jika melihat pada penelitian yang dilakukan oleh Aulia (2015) dijelaskan bahwa, psikologi positif memiliki peran dalam konteks pendidikan, salah satunya yaitu dapat membuat seseorang memiliki engagement dalam proses belajarnya.

Dari hasil penelitian ini juga bisa ditemukan beberapa hal, salah satunya yaitu jika mengutip pada penelitian yang dilakukan oleh Prajitno (2015) yang mengatakan bahwa PWB memiliki korelasi positif dengan prestasi akademik dan jika mengutip pada penelitian yang dilakukan oleh Aslamawati, Enoch \& Halimi (2015) mengatakan bahwa college engagement memiliki korelasi positif dengan prestasi akademik, maka bisa dikatakan baik PWB maupun college engagement sama-sama berkorelasi positif dengan prestasi akademik. Lebih lanjut jika memperhatikan pada hasil penelitian yang dilakukan oleh peneliti, yang dimana PWB berkorelasi positif dengan engagement learning, maka bisa dikatakan dengan semakin tinggi PWB pada mahasiswa maka semakin tinggi pula engagement learning pada mahasiswa tersebut, sehingga dengan diperolehnya enggaement learning yang tinggi pada mahasiswa tersebut akan mengarahkan mahasiswa tersebut dalam memperoleh prestasi akademik yang baik pula. Hal ini sejalan dengan pernyataan menurut Hyde (2009) yang mengatakan bahwa, siswa yang terlibat dalam kegiatan belajar, terutama di kelas, jauh lebih mungkin memiliki prestasi yang baik dibandingkan dengan yang tidak terlibat dalam kegiatan tersebut.

Lebih lanjut dalam teori Ryff dan Singer (1996) dijelaskanan bahwa seseorang yang memiliki PWB yang tinggi: akan 
memiliki karakteristik seperti menerima dirinya, baik itu aspek positif dan aspek negatif; dapat berhubungan interpersonal secara positif dengan lingkunganya; mandiri dan menilai berdasarkan personal serta tidak tergantung pada orang lain; menciptakan dan mengelola lingkungan yang sesuai dengan pertumbuhan karakternya; memiliki tujuan hidup; serta mengembangkan potensi individu yang ia miliki. Karakteristik yang sudah dijelaskan sebelumnya terkait seseorang dengan PWB yang tinggi seperti, dapat berhubungan interpersonal secara positif dengan lingkunganya, mandiri dan menilai berdasarkan personal serta tidak tergantung pada orang lain, sesuai dengan faktor-faktor yang dapat meningkatkan engagement learning seseorang menurut Fredericks, Blumenfeld \& Paris (2004) yaitu, mulai dari faktor yang berasal dari dalam diri individu yaitu need for autonomy, dimana seseorang yang terpenuhi need for autonomy dalam dirinya cenderung melakukan sesuatu atas kemauan dari dalam dirinya sendiri tanpa kontrol atau pengaruh dari lingkungan luarnya, sehingga individu tersebut lebih terlibat dalam pengerjaan tugas-tugas, partisipasi dalam diskusi di kelas serta memunculkan emosi positif seperti minat dan kebahagiaan. Faktor lainya yang dapat meningkatkan engagement learning seseorang yang berasal dari luar individu yaitu faktor peers, dimana dengan memiliki relasi yang baik dengan orang lain atau teman kuliah, seseorang tersebut bisa mendapatkan dukungan dari temanya dan membuat mahasiswa lebih berminat dalam mengikuti perkuliahan serta timbulnya rasa aman dan nyaman dalam melaksanakan proses perkuliahan, yang mana hal ini sejalan dengan pernyataan Furrer \& Skinner dalam Halimah, Kusdiyati \& Susandar (2017) yang mengatakan bahwa, adanya rasa aman pada siswa akan membuat siswa merasa bebas untuk mengeksplorasi lingkungan dan untuk terlibat secara konstruktif dalam setiap aktivitas-aktivitas yang dilakukannya dan dalam berinteraksi dengan orang lain. Sehingga berdasarkan penjelasan di atas bisa disimpulkan bahwa terdapat beberapa karakteristik yang ada pada PWB seperti dapat berhubungan interpersonal secara positif dengan lingkunganya, kemudian mandiri dan menilai berdasarkan personal serta tidak tergantung pada orang lain, berhubungan dangan faktor-faktor yang dapat meningkatkan engagement learning seseorang. Hal ini juga didukung dengan hasil penelitian yang mengatakan bahwa dimensi autonomy berkorelasi dengan engagement learning dengan hasil korelasi (r) sebesar 0,359 dan signifikansi sebesar $0,000(\mathrm{p}<$ 0,05) dan dimensi relations with others berkorelasi dengan engagement learning dengan nilai korelasi (r) sebesar 0,393 dan signifikansi sebesar 0,000 $(\mathrm{p}<0,05)$.

Dalam penelitian ini juga menunjukan bahwa keenam dimensi yang ada pada PWB memiliki korelasi yang signifikan dengan engagement learning, mulai dari dimensi self acceptance, keinginan untuk memiliki hubungan yang berkualitas dengan orang lain 
(positive relations with others), perasaan untuk menjadi pribadi yang mandiri (autonomy), kapasitas untuk mengendalikan hidup dan lingkungan secara efektif (environmental mastery), keyakinan bahwa kehidupan seseorang memiliki tujuan dan arti (purpose in life) dan perasaan untuk terus bertumbuh dan berkembang secara personal (personal growth).

Dari keenam dimensi yang ada pada PWB yang telah dijelaskan sebelumnya, dimensi environmental mastery memiliki korelasi yang paling tinggi dengan enggament learning dibandingkan dengan dimensi lainnya yang ada pada PWB, yaitu dengan nilai korelasi (r) sebesar 0,478 dan signifikansi sebesar 0,000 ( $p<0,05)$. Individu yang terpenuhi untuk dimensi ini maka individu tersebut mampu menciptakan dan mempertahankan lingkungan yang memberikan manfaat positif bagi dirinya (Ryff \& Singer, 2003). Mahasiswa yang mampu menciptakan serta mempertahankan lingkungan yang memberikan manfaat positif bagi dirinya dimanapun dia berada tentu bisa menyesuaikan kondisi selama proses belajar ketika berada dikelas, baik itu saat berada di kelas maupun bereaksi terhadap tugas kuliah yang ada, sehingga individu dalam hal ini bisa dikatakan dapat mengontrol lingkungan kuliah pada saat dia menjalani proses belajar di kuliah, oleh karena itu hal seperti tekanan tugas kuliah maupun ujian tidak begitu menjadi masalah bagi mahasiswa tersebut. Dengan mampunya mahasiswa mengontrol dan menciptakan lingkungan yang positif pada dirinya, maka hal tersebut juga mengarah kepada terciptanya emosi yang positif seperti minat, kebahagian, pada saat mahasiswa berada di kelas. Dengan adanya emosi positif pada mahasiswa maka energi yang dihasilkan pun juga energi yang positif, sehingga dengan energi positif inilah akan membuat mahasiswa memiliki engagement dalam proses belajarnya. Hal ini juga sesuai dengan definisi engagement learning itu sendiri yaitu, suatu energi positif yang diberikan dalam pembelajaran sendiri, yang dibuktikan dengan meaningful processing, perhatian pada apa yang terjadi pada saat ini, dan keterlibatan dalam kegiatan pembelajaran (Schreiner \& Louis, 2006).

Hasil penelitian lainya juga dapat dilihat dalam penelitian ini yaitu, PWB memberikan sumbangan efektif pada enggagement learning pada mahasiswa dengan kontribusi sebesar $24,8 \%$. Sisanya yaitu $75,2 \%$ dipengaruhi oleh faktor lain seperti dukungan dari dosen, teman atau kelompok dekat selama berada di kelas, tugas yang diberikan, serta faktor lain seperti keinginan dalam berkompetesi dan emosi positif atau perasaan nyaman ketika berada di kelas. Hal ini sesuai dengan penelitian menurut Fredericks, Blumenfeld \& Paris (2004) yang mengatakan faktor-faktor yang memengaruhi engagement individu dalam proses belajarnya antara lain classroom context yang terdiri dari; teacher support, peers, classroom structure, autonomy support, task characteristics, serta faktor yang terakhir yaitu individual needs yang terdiri dari; need 
for relatedness yang didefinisikan sebagai kebutuhan untuk merasa aman dalam menjalin relasi sosial dengan lingkungan sekitar dan kebutuhan untuk mendapatkan pengalaman bahwa dirinya adalah orang yang berguna, orang yang mampu memberikan cinta dan penghargaan; need for autonomy di definisikan sebagai keinginan untuk melakukan sesuatu karena alasan pribadi, daripada melakukan sesuatu karena dipengaruhi oleh orang lain; need for competence didefinisikan sebagai kebutuhan untuk mengalami diri sebagai orang yang mampu memproduksi hasil yang diinginkan dan menghindari hasil yang negatif.

Pada penelitian ini juga menunjukan bahwa dari 91 mahasiswa fakultas psikologi UKSW, terdapat 15 mahasiswa dengan PWB yang tinggi dan terdapat 19 mahasiswa yang dengan engagement learning yang tinggi, hal ini dimungkinkan terjadi karena sistem pengajaran yang dibangun selama mahasiswa menjalani proses belajar di kelas, bisa membuat mahasiswanya merasa terlibat dalam proses belajar serta kurangnya tekanan maupun stres yang didapatkan selama menjalani proses belajar. Peran dukungan dari orang lain juga berpengaruh dalam hal ini seperti peran peers dan dukungan dari dosen, hal ini juga diperkuat dari penelitian yang menyatakan semakin besar dukungan sosial yang dirasakan, akan memberi kontribusi yang signifikan terhadap psychological wellbeing yang lebih baik (Sood \& Bakshi, 2012). Penelitian lainya yang juga memperkuat hal ini yaitu menurut Fredericks, Blumenfeld \&
Paris (2004) yang mengatakan bahwa peers dan teacher support berperan dalam meninggkatkan engagement learning seseorang.

\section{PENUTUP}

Berdasarkan pada hasil penelitian yang telah dilakukan, maka kesimpulan dari penelitian ini adalah:Terdapat hubungan positif dan signifikan antara psychological well-being dengan engagement learning pada mahasiswa. Hal ini juga menujukan semakin tinggi psychological well-being pada mahasiswa maka semakin tinggi pula engagement learning pada mahasiswa tersebut, begitu pula sebaliknya. Keenam dimensi yang ada pada psychological wellbeing yang terdiri dari self acceptance, positive relations with others, autonomy, environmental mastery, purpose in life dikatakan berkorelasi positif dan signifikan dengan engagement learning dan dimensi enviromental mastery memiliki korelasi yang paling tinggi dibandingkan dengan ke enam dimensi lainya. Selain psychological wellbeing memiliki kontribusi terhadap engagement learning juga terdapat beberapa faktor lain yang dapat memengaruhi engagement learning mahasiswa antara lain; dukungan dari dosen, teman atau kelompok dekat selama berada di kelas, tugas-tugas yang diberikan, serta faktor lain seperti yang berasal dari individu yaitu need for autonomy,need for competence,need for relatedness dan emosi positif ketika berada di kelas. 


\section{DAFTAR PUSTAKA}

Arlinkasari, F., \& Akmal, S. Z. 2017. Hubungan Antara School Engagement, Academic Self-efficacy dan Academic Burnout pada mahasiswa. Humanitas Jurnal Psikologi, 1(2), 81-102.

Aulia, F. 2015. Aplikasi Psikologi Positif dalam Konteks Sekolah. In Seminar Psikologi dan kemanusian

Awang-Hashim, R., Kaur, A., \& Noman, M. 2015. The interplay of sociopsychological factors on school engagement among early adolescents. Journal of Adolescence, 45, 214-224.

Azwar, S. 2011. Metode Penelitian. Yogyakarta: Pustaka Pelajar

Azwar, S. 2012. Penyusunan Skala Psikologi. Yogyakarta Pustaka Pelajar.

Ceyhan, A. A., \& Ceyhan, E. 2011. Investigation of university students' selfacceptance and learned resourcefulness: A longitudinal study. Higher Education, 61(6), 649-661.

Fredricks, J. A., Blumenfeld, P. C., \& Paris, A. H. 2004. School engagement: Potential of the concept, state of the evidence. Review of educational research, 74(1), 59-109.

Halimah, L., Kusdiyati, S., \& Susandari, S. 2017. Pengaruh Konteks Teman Sebaya Terhadap Keterlibatan Belajar Dengan Mediator Self-System Processes. Psympathic: Jurnal Ilmiah Psikologi, 4(2), 265-274.

Maharani, R. 2015. Pengaruh Penerimaan Diri Terhadap Psychological Well Being Pada Narapidana Remaja Tahanan Polres Banyumas Yang Mengalami Kecanduan Napza Di Lembaga Pemasyarakatan Purwokerto. Skripsi. Tidak diterbitkan. Fakultas Psikologi. Purwokerto : Universitas Kristen Satya Wacana

Mangaria, S. 2017. Hubungan work engagement dengan pyschological well
Being Pada Orang Yang Profesinya Berbeda Dengan Latar Belakang Pendidikanya.Skripsi. Tidak diterbitkan. Fakultas Psikologi. Salatiga : Universitas Kristen Satya Wacana

Mariyanti, S. 2017. Profil Psychological Well Being Mahasiswa Reguler Program Studi Psikologi Semester 1 di universitas esa unggul. Jurnal Psikologi: Media Ilmiah Psikologi, 15 (2), 45- 50.

Michael, K. D., Huelsman, T. J., Gerard, C., Giligan, T. M., \& Gustafson, M.R. (2006). Depression among college students trends In prevalance and treatment seeking. Counseling and Clinical Psychology Journal, 3(2), 60-70.

Oetari, R., Psi, S. P. S., \& Psi, M. 2018. Hubungan Antara Pemaafan Dengan Psychological Well-Being Pada Mahasiswa Fakultas Psikologi Universitas Muhammadiyah Surakarta. Skripsi. Tidak diterbitkan. Fakultas Psikologi. Surakarta : Universitas Muhammadiyah Surakarta

Prajitno, E.D. 2015. Hubungan Psychological Well Being dengan Prestasi Akademis pada Mahasiswa Fakultas Psikologi Universitas Kristen Satya Wacana. Skripsi. Tidak diterbitkan. Fakultas Psikologi. Salatiga : Universitas Kristen Satya Wacana.

Ryff, C. D. 1989. Happiness is everything, or is it? Explorations on the meaning of psychological well-being. Journal of personality and social psychology, 57(6), 1069-1081.

Ryff, C. D., \& Singer, B. 1996. Psychological Well-Being: Meaning, Measurement, And Implications For Psychotherapy Research. Psychotherapy and psychosomatics, 65(1), 14-23.

Santoso, S. 2000. SPSS Versi Mengelolah Data Statistik Secara Profesional. Jakarta: PT. Elex Media Komputindo.

Santrock. J. W. 2002. Life- span development: Perkembangan masa hidup. Jakarta: Erlangga. 
Schreiner, L. A., \& Louis, M. 2006. Measuring engaged learning in college students: Beyond the borders of NSSE. Paper presented at the annual meeting of the Association for the Study of Higher Education, Anaheim, CA.

Ludban, M. 2015. Psychological Well-Being Of College Students. Undergraduate Research Journal for the Human Sciences, 14 (1).

Sarifah, S., \& Edwina, T. N. 2015. Hubungan Antara Dukungan Sosial Teman Sebaya Dan Disiplin Kuliah Dengan Minat Mengikuti Kuliah Pada Mahasiswa Program Studi Manajemen Produksi Pemberitaan Sekolah Tinggi Multi Media Yogyakarta. Insight: Jurnal Ilmiah Psikologi, 17(2), 118-127.
Sood, S., \& Bakhshi, A., 2012. Percieved social support and psychological wellbeing of aged Kashmiri migrants. Research on Humanities and Social Sciens, 2(2), 1-7.

Undang- Undang Republik Indonesia Nomor 20 Tahun 2003. Sistem Pendidikan Nasional. 2003. Keputusan Presiden Republik Indonesia. Jakarta

Zulkifli, H, R, A. 2018. Pengaruh Grit, Syukur Dan School Engagement Terhadap Kesejahteraan Subjektif Mahasiswa Perantau. Skripsi. Tidak diterbitkan. Fakultas Psikologi. Jakarta : Universitas Islam Negeri Syarif Hidayatullah 